Elke Freier, Stefan Grunert and Michael Freitag: Reise durch Ägypten. Nach Zeichnungen der Lepsius-Expedition 1842-1845 [Travel in Egypt. According to Drawings of the Lepsius-Expedition 1842-1845] 5th ed. Pp. 184. Edition Leipzig, Leipzig 1996. DM 68.00. Nancy Thomas, Gerry D. Scott III and Bruce G. Trigger: American Discovery of Ancient Egypt. Pp. 276. Abrams, New York 1995.

Siehr, Kurt

DOI: https://doi.org/10.1017/s0940739197000490

Posted at the Zurich Open Repository and Archive, University of Zurich ZORA URL: https://doi.org/10.5167/uzh-154388

Journal Article

Published Version

Originally published at:

Siehr, Kurt (1997). Elke Freier, Stefan Grunert and Michael Freitag: Reise durch Ägypten. Nach Zeichnungen der Lepsius-Expedition 1842-1845 [Travel in Egypt. According to Drawings of the LepsiusExpedition 1842-1845] 5th ed. Pp. 184. Edition Leipzig, Leipzig 1996. DM 68.00. Nancy Thomas, Gerry D. Scott III and Bruce G. Trigger: American Discovery of Ancient Egypt. Pp. 276. Abrams, New York 1995. International Journal of Cultural Property, 6(2):421-423.

DOI: https://doi.org/10.1017/s0940739197000490 


\section{Kurt Siehr*}

Elke Freier, Stefan Grunert and Michael Freitag: Reise durch Ägypten. Nach Zeichnungen der Lepsius-Expedition 1842-1845 [Travel in Egypt. According to Drawings of the Lepsius-Expedition 1842-1845] 5th ed. Pp. 184. Edition Leipzig, Leipzig 1996.DM 68.00.

Nancy Thomas, Gerry D. Scott, III and Bruce G. Trigger: American Discovery of Ancient Egypt. Pp. 276. Abrams, New York 1995.

In recent years there has been a growing interest in Egyptian art, Egyptian civilization ${ }^{1}$ and the modern discovery of Egypt since the expedition of Napoleon in $1798 / 99 .{ }^{2}$ While some source countries are sometimes reluctant to send their cultural heritage abroad, ${ }^{3}$ museums of Europe and America are exchanging their treasures from Africa, Asia and Latin America ${ }^{4}$

From 1842 to 1845 the German Egyptologist Karl Richard Lepsius (1810-1884) was commissioned by the Prussian King Frederick William IV to explore Egypt. The result of this expedi-

* Professor of Law, University of Zürich. tion was published by 1859 in twelve volumes and comprised almost 1000 copper engravings. ${ }^{5}$ Reise durch Ägypten, which is edited by two German Egyptologists and collaborators of the "Old Egyptian Dictionary," describes a journey across Egypt which follows the route of the Lepsius expedition. The work, which is illustrated by drawings made during the expedition, by modern reproduction of art objects and by photographs, recalls the early days of archaeological research.

American Discovery of Ancient Egypt is a catalogue of a 1996 exhibition organized by the Los Angeles County Museum of Art and the American Research Center in Egypt. The catalogue, which describes the 150 objects exhibited in Los Angeles, Saint Louis and Indianapolis, is preceded by three essays. Nancy Thomas, the curator of ancient and Islamic art in the Los Angeles County Museum of Art, invited two specialists to write essays on "Egyptology, Ancient Egypt and the American Imagination" (Bruce G. Trigger) and "Go Down into Egypt: The Dawn of American Egyptology" (Gerry D. Scott, III); she herself tells about "American Institutional Fieldwork in Egypt, 1899-1960." 
These essays and the list "Archaeological and Research Expeditions to Egypt and Nubia Sponsored by North American Institutions" draw a lively picture of American activities in Egypt, such as James Henry Breasted (1865-1935) of the University of Chicago and George A. Reisner (1867-1942) of Harvard University. The transfer of the obelisk of Alexandria to New York's Central Park is mentioned. This obelisk was offered to the United States by the Khedive Ishmail and the removal from Alexandria had to be enforced against private parties (land owners and creditors of Egypt) ${ }^{6}$

In the 19th century archaeology in Egypt was characterized by national rivalries and by irregularities and rapes. ${ }^{7}$ Whether any finds illegally or legally removed in the past may be returned in the future ${ }^{8}$ seems to be doubtful. ${ }^{9}$ Today, however, all nations should help to preserve the Egyptian past. This has been done jointly, for example, by the Getty Conservation Institute and the Egyptian Antiquities Organization with respect to the Nefertari wall paintings in the tomb of queen Nefertari (wife of pharaoh Rameses II, ca. $1290-1224$ B.C.E. $)^{10}$ discovered by the Italian egyptologist Ernesto Schiaparelli in 1904 in the Valley of the Queens west of Luxor (Thebes). With respect to movable cultural property, the trend of reclaiming art treasures should be succeeded by international cooperation, by long term loans and by a sharing of profits collected by the borrower with the lending institution.

\section{Notes}

I See, e. g., James Stevens Curl, Egyptomania. THE EgYPTIAN REvival: A RECURRING THEME IN THE HISTORY OF TASTE. (Manchester University Press, Manchester, New York 1994).

2 See DesCriPtION DE L'ÉGYPTE OU RECUEIL DES OBSERVATIONS ET DE RECHERCHES QUI ONT ÉTÉ FAITES EN ÉGYPTE PENDANT L'EXPÉDITION DE L'ARMÉE FRANÇAISE PUBLIÉ SOUS L'ORDRE DE NAPOLÉON BONAPARTE (Paris). Image reprint 1995 of the edition of 1822, FERNAND BEAUCOUR, Yves LaISSUS \& CHANTAL ORGOGOZO, LA DÉCOUVERTE DE L'ÉGYPTE (Flammarion, Paris 1989).

3 See David D'Arcy, A Pyramid scheme collapses. Cairo court forbids loan of seventy-two antiquities to US-blockbuster despite promised \$2 million fee. THE ART NEWSPAPER, Feb. 1996, at 10.

4 See, e. g., Robert Steven Bianchi, Splendours of Ancient Egypt from Hildesheim. 7 Minerva no. 4, p. 10 (1996).

5 LEPSIUS, DENKMÄLER AUS ÄGYPTEN UND ÄTHIOPIEN, BERLIN 1849-1859 (K. Sethe, L. Borchardt \& W. Wreszinski eds., text volumes, Leipzig 1897-1913). According to Brian M. Fagan, RAPE OF THE NILE 266 (1992), these volumes of Lepsius are "probably the largest work on Egyptology ever published."

6 See Labib Habachi, The ObeLISKS OF EGYPT: SKYSCRAPERS OF THE PAST chap. 7 (Cairo 1984); Martina D'Alton, The New YORK OBELISK OR HOW ClEOPAT- 
RA'S NEEDLE CAME TO NeW York aND What HaPPENED WHEN IT GOT HERE (New York 1993).

7 See Brian M. Fagan, The Rape of the Nile. Tomb Robbers, TOURISTS AND ARCHAEOLOGISTS IN EGYPT (Wakefield, London 1992).

8 See L'Egitto rinuncia alle restituzioni. La Stele di Rosetta per sem- pre a Londra. IL GIORNALE DELL' ARTE, Apr. 1997, at 28.

9 International instruments on cultural property do not work retroactively.

10 See Art and Eternity. The Nefertari Wall Paintings Conservation Project 1986-1992 (Miguel Angel Corzo and Mahasti Afshar eds., Malibu 1993). 